\title{
UNCITRAL RECEIVABLES \\ CONVENTION: THE POSSIBILITY FOR TRANS-TASMAN HARMONISATION
}

\author{
Malcolm McKinnon*
}

This paper examines the UNCITRAL Convention on the Assignment of Receivables in International Trade as it affects New Zealand. The focus of the paper is on the potential effect of the Convention on New Zealand's relationship with Australia. The law in the two countries is very different especially since the passing of New Zealand's Personal Property Securities Act 1999, which is, the author concludes, highly compatible with the UNCITRAL Receivables Convention. The paper considers two sample transactions to illustrate the effects of the Convention in a transTasman context. It concludes that where the Convention (if it enters into force in New Zealand and Australia) applies, there are relatively few complications. Where it does not apply, however, parties to trans-Tasman receivables transactions face complicated applicable law arguments and general uncertainty.

\section{INTRODUCTION}

New Zealand is a country that relies on international trade. As a consequence, transactions that extend beyond national boundaries are of considerable importance. Despite the significance of international trade, however, the parties involved face considerable legal risks and uncertainty. The very essence of international trade creates uncertainty since the international transactions that facilitate this trade cross national boundaries, requiring knowledge of the law in one or more jurisdictions. Coupled with this inherent uncertainty, direct risks include the possibility of becoming a party to a dispute that involves the laws, or courts, of one or more country. It has been observed that cross border legal issues are costly and that they inhibit business opportunities. ${ }^{1}$ This

* This article is an edited version of a paper submitted in fulfilment of the requirements of the LLB(Hons) degree at Victoria University of Wellington, 2002.

1 Australian Law Reform Commission Legal Risks in International Transactions (ALRC R80, Canberra, 1996) < http://www.austlii.edu.au/au/other/alrc/publications/reports/80/ALRC80.html $>$ (last accessed 2 August 2002). 
is true for all types of international transactions but, arguably, it is particularly relevant for financing transactions given the prevalence of competing claimants.

The increased cost to international transactions is unfavourable and increasingly avoidable. This is a result of the growing interest in the harmonisation of international commercial law. Recently, the New Zealand Law Commission commentated that "harmonising international trading laws can only assist a nation as economically dependant on international trade as is New Zealand". ${ }^{2}$ One organisation at the vanguard of this movement is the United Nations Commission on International Trade Law (UNCITRAL). The UNCITRAL was founded in 1966 with a mandate "to further the progressive harmonisation and unification of the law of international trade". ${ }^{3}$ Benefits of harmonisation include increased certainty and lower transaction costs. Despite significant achievements, however, not enough is known in New Zealand about the UNCITRAL and its work. ${ }^{4}$

Most recently, the UNCITRAL has completed its work on the multilateral Convention on the Assignment of Receivables in International Trade ("the Receivables Convention"). ${ }^{5}$ The Receivables Convention is currently open for signature and ratification, with the potential to bring a degree of uniformity to the laws relating to receivables financing, and thus provide greater certainty and reduced transaction costs.

This paper will examine the Receivables Convention and provide an analysis of its potential effect in a trans-Tasman context. This is particularly topical since the enactment of the Personal Property Securities Act 1999 (PPSA) in New Zealand has altered the law significantly in comparison with Australia. ${ }^{6}$ The central question this paper considers is the Receivables Convention's effect on the process of harmonising trans-Tasman commercial law in the area of receivables financing. It is argued that harmonisation would alleviate some of the difficulties facing trans-Tasman receivables financing.

The analysis in this paper is presented in three stages. First, the paper highlights the disparity within the law applicable to trans-Tasman receivables financing and presents the case for harmonisation of these laws. Second, the Receivables Convention is introduced as a means of achieving a degree of uniformity across the Tasman. The provisions of the Receivables Convention

2 New Zealand Law Commission Arbitration (NZLC R20, Wellington, 1991) para 78.

3 General Assembly Resolution 2205 (XXI). UNCITRAL < http://www.uncitral.org/en-index.htm> (last accessed 29 July 2002).

4 Giora Sharipa "UNCITRAL and its Work - Harmonisation and Unification of International Trade Law" [1992] NZLJ 309.

5 The Receivables Convention was adopted by United Nations General Assembly Resolution 56/81. The text of the Convention is available on the UNCITRAL web-site at: <http://www.uncitral.org $>$ (last accessed 5 August 2002).

6 The New Zealand Personal Property Securities Act 1999 (PPSA) entered into force in May 2002. 
are outlined and their compatibility with the PPSA assessed. Finally, two sample transactions will illustrate the potential effects of the Receivables Convention when applied in a trans-Tasman context. The conclusions will assess the effect of the Convention on trans-Tasman receivables financing and will comment on the likelihood of ratification in New Zealand and Australia.

\section{TRANS-TASMAN RECEIVABLES FINANCING}

Receivables are simply understood as claims for the payment of money and they are among the most important of company assets. For example, account receivables arise whenever a seller supplies goods to a purchaser on credit, and consequently, the purchaser owes a monetary obligation to the seller. In developed countries it is reported that the bulk of corporate wealth is locked up in receivables. ${ }^{7}$

Receivables financing encompasses a broad range of complex commercial practices, including factoring, securitisation, project finance and asset based lending. For the purposes of this paper, however, the practice known as factoring provides a useful example. Hammond $\mathrm{J}$ gave a clear description of the practice of factoring in New Zealand in Commercial Factors Ltd $v$ Maxwell Printing $L t d:{ }^{8}$

[i]n commercial terms, factoring involves the creditor transferring to a third party the ability to receive the proceeds of a debt in return for an invariably discounted sum of money. The creditor's position is thereby improved by immediate cash flow; and the often onerous task of recovering receivables is avoided so that the creditor can concentrate on production and marketing, rather than chasing debtors.

The factoring entity of course takes a risk on recovery, but endeavours to protect itself in various ways.

Trade New Zealand reports that the creditor receives around eighty percent of face value for the sale of their receivables in a typical factoring transaction. ${ }^{9}$ The discounted price reflects the reality that the risk of non-payment is transferred to the factor. This is an effective means of raising capital but there are associated risks. In Commercial Factors Ltd $v$ Maxwell Printing Ltd Hammond J discusses two difficulties with factoring transactions.

The first difficulty Hammond $\mathrm{J}$ addresses is the complexity of the law involved. He comments that "factoring agreements and arrangements are governed by bodies of law which are notoriously difficult of application". ${ }^{10}$ At the core of this complexity is the fact that a factoring agreement usually involves some form of assignment. This requires two sets of contractual relations: the

7 Spiros V Bazinas "An International Legal Regime for Receivables Financing: UNCITRAL's Contribution" (1999) 8 Duke J Comp \& Int'l L 315, 315.

$8 \quad$ Commercial Factors Ltd v Maxwell Printing Ltd [1994] 1 NZLR 724, 727 (HC) Hammond J.

9 Trade New Zealand "Private Sector Export Financing". Available online $<$ http://www.tradenz.govt.nz/page_Article/0,1300,4231\%252D847,00.html > (last accessed 31 July 2002).

10 Commercial Factors Ltd v Maxwell Printing Ltd, above. 
original contract between the creditor and debtor, and the contract between the assignor (creditor) and the assignee, by which the assignment of the receivable is achieved. The law of assignment, however, is described as "a complex matrix"11 that is "either uncertain, fragmentary or outdated". ${ }^{12}$ This complexity can increase transaction costs and potentially result in complex litigation in the event that the courts are required for the assignee/factor to enforce their interest.

The second difficulty to which Hammond J draws attention is the potential for the factor to have their interest subordinated to a competing claimant in a priority dispute". ${ }^{13}$ In such a scenario, when one party divests its proprietary rights in favour of another, the rights of competing third parties will often come to the forefront. This is a particular problem in the case of receivables since the transfer of the collateral is not physically apparent. Competing claimants might include other assignees to the same receivable, creditors of the assignor or the assignor's insolvency administrator. Consequently, from the perspective of the factor/assignee, there must be some certainty with respect to their priority and the enforceability of their right to the payment. The absence of certainty in the assignee's interest presents a significant difficulty to receivables financing. Depending upon the degree of certainty, the cost of credit available to the assignor will increase, or at worst, become unavailable. ${ }^{14}$

It is important not to overlook the implications of a third complicating issue in trans-Tasman receivables financing - the international context. This is a complex matter as currently there are fundamental differences in the legal regimes governing these transactions in New Zealand when compared with Australia. New Zealand enacted the PPSA providing a single statute expected to make transactions involving personal property less complicated, more secure, and ultimately cheaper. The current law in Australia governing personal property securities is similar to the old regime in New Zealand in that it is a matrix of rules governed by statute, common law, and equity. The situation in Australia is even more confused owing to the fact that Australia is plagued by diversity within its federal system. David Allan, an Australian academic advocating for reform, describes the Australian situation as "horrific". ${ }^{15}$

11 Catherine Walsh "Receivables Financing and the Conflict of Laws: The UNCITRAL Draft Convention on the Assignment of Receivables in International Trade" (2001) 106 Dick L Rev 159, 160.

12 Spiros V Bazinas "An International Legal Regime for Receivables Financing: UNCITRAL's Contribution" (1999) 8 Duke J Comp \& Int'1 L 315, 315.

13 Commercial Factors Ltd v Maxwell Printing Ltd [1994] 1 NZLR 724, 727 (HC) Hammond J. Hammond J comments on the reality that "the factor lives in fear that some right of set-off exists between the (original) creditor and debtor which may be able subsequently to be raised against that factor."

14 Sprios V Bazinas "Lowering the Cost of Credit: The Promise in the Future UNCITRAL Convention on Assignment of Receivables in International Trade" (2001) 9 Tul J Int'l \& Comp L 259, 261.

15 David Allan "Personal Property Security - A Long Long Trail A-Winding" (1999) 11 Bond LR 178, 181. 
Of particular relevance to this discussion is Allen's observation of the "ease with which all forms of personal property can bridge the Tasman". ${ }^{16}$ Ease, however, should not be mistaken for simplicity. Once this international element applies, conflict-of-laws problems arise, and an already complicated area of the law becomes much more complicated. For example, New Zealand parties entering into transactions with Australian parties may be required to structure their transactions with regard to the law in Australia - and as mentioned, the law in Australia is in an unhappy state. Further, if a dispute arises and litigation ensues, a complex conflict-of-laws argument may ensue which will add to the costs and complexity of litigation. Ultimately, working with the law of a foreign jurisdiction can lead to confusion, and confusion is costly.

It is thought by many that the road to simpler and cheaper transactions is paved with harmonisation. This is part of the impetus behind the Australia and New Zealand Closer Economic Relations Trade Agreement (CER). ${ }^{17}$ This agreement recognises benefits in harmonisation and seeks to promote that objective. ${ }^{18}$

In relation to transactions involving personal property, of which receivables are a species, the need for harmonisation of the law in this area does not go unnoticed. David Allan, Professor of Law at Bond University, and advocate for an Australian personal property securities Act, comments: "if closer economic relations with New Zealand are to mean anything ... this [the New Zealand PPSA] should surely operate as a spur to Australia [to enact similar legislation]". ${ }^{19}$ In addition, Bob Dugan, a New Zealand academic, notes: "the enactment of the PPSA [in New Zealand] surely contravenes the spirit of CER". ${ }^{20}$ The purpose of this paper is not to advocate that Australia should enact its own personal property securities Act, nor is it to detract from the New Zealand legislation. Rather, the point to be made is two-fold: that the law is different in these respective jurisdictions and that there are perceived benefits in a degree of harmonisation. ${ }^{21}$

Recently, the New Zealand Law Commission noted that the harmonisation of rules governing cross border transactions could facilitate trade, and that international conventions have a part to play

16 Allan, above, 184.

17 The Closer Economic Relations Trade Agreement (CER) was entered into by the Australian and New Zealand Governments on 13 April 1982.

18 It is important to note however, that the CER does not require identical legislation or policies: John Farrar "Harmonisation of Business Law Between Australia and New Zealand" (1989) 19 VUWLR 435, 445-446.

19 Allan, above, 184

20 Bob Dugan "PPSA - The Price of Certainty" [2000] NZLJ 241.

21 The Receivables Convention purports to bring a degree of harmonisation at the international level. It does not require unity at the national level. It will however supersede national law in respect of transactions that come within its scope. In the trans-Tasman context, when the Receivables Convention is applicable to a transaction, the differing legal regimes will become less of a barrier since issues covered by the Convention will have a uniform rule. 
in achieving uniformity. ${ }^{22}$ One recent development that might alleviate some of the difficulties facing trans-Tasman receivables financing is the UNCITRAL Receivables Convention.

\section{UNCITRAL RECEIVABLES CONVENTION}

The following is a brief outline of the rules established in the Receivables Convention. Owing to the size constraints of the present paper it is not possible to examine each individual article. Therefore, the rules presented are selected because of their importance to receivables financing generally, their relationship to the sample transactions that follow, and because of their potential impact. Where relevant the corresponding domestic rules of New Zealand are provided and similarities and differences with the Receivables Convention are discussed.

\section{A Purpose and Applicability of the Receivables Convention}

The Receivables Convention purports to create a uniform law that will increase predictability and certainty in international receivables financing - thus potentially decreasing the cost and increasing the availability of credit based on receivables. According to Spiros Bazinas, one of the drafters of the Receivables Convention, the key to understanding the Convention is the objective of facilitation of access to lower cost credit. However, the drafters were cognisant of the many effects that an assignment can have upon a debtor, and consequently many provisions reflect the principle of debtor protection as established in the Preamble to the Convention. ${ }^{23}$

It is anticipated that the uniform rules will benefit all parties involved in receivables financing transactions. ${ }^{24}$ First, assignors - suppliers of goods - will benefit from the increased access to credit. Second, assignees - financial institutions or other financiers - will benefit from the increased certainty of the enforceability of their security interests. Finally, debtors - the purchasers of goods - will benefit because their rights and obligations will be more clearly defined and harmonised.

The applicability of the Receivables Convention extends to cover both the assignments of international receivables, as well as to the international assignment of receivables. ${ }^{25}$ Article 3 provides the test for "internationality":26

22 New Zealand Law Commission International Trade Conventions (NZLC SP 5, Wellington, 2000) para 3.

23 Receivables Convention, Preamble. The Convention purports to ensure adequate protection of the interests of debtors in assignments of receivables. One obvious effect that an assignment can have upon a debtor is changing the party to which they owe payment.

24 Mara E Trager "Towards a Predictable Law on International Receivables Financing: The UNCITRAL Convention" (1999) 31 NYU J Int L \& Pol 611, 620.

25 Receivables Convention, Article 1(1)(a).

26 Receivables Convention, Article 3. 
A receivable is international if, at the time of conclusion of the original contract, the assignor and the debtor are located in different States. An assignment is international if, at the time of conclusion of the contract of assignment, the assignor and the assignee are located in different States.

For the purposes of the Receivables Convention, "assignment" means: ${ }^{27}$

[T] he transfer by agreement from one person ("the assignor") to another person ("the assignee") of all or part of an undivided interest in the assignor's contractual right to payment of a monetary sum ("a receivable") from a third person ("the debtor").

To ensure the broadest coverage possible, the Receivables Convention is applicable if at the time of the conclusion of the original contract, the assignor is located in a Contracting State - the assignee need not be. ${ }^{28}$ This approach to the territorial application is based on the assumption that the main disputes that the Receivables Convention would be called upon to resolve would be addressed if the assignor were located in a Contracting State; such as defences of the debtor against the assignee. ${ }^{29}$ As a result, parties to international receivables financing transactions could come within the ambit of the Receivables Convention despite the fact that the state in which they are located is not a party to the Convention. ${ }^{30}$ For example, if New Zealand is a Contracting State and the assignor in a receivables financing transaction involving an Australian party is located in New Zealand, then the Receivables Convention is applicable to the transaction - even if Australia is not a party to the Convention. Additionally, both absolute assignments and assignments that create security interests are covered by the Receivables Convention. ${ }^{31}$ This is complementary to the PPSA. ${ }^{32}$ With these rules in mind, it is fair to conclude that the Convention takes an inclusive approach to applicability. This helps achieve the Convention's purposes by ensuring that a large number of transactions will come within its ambit.

27 Receivables Convention, Article 2(a).

28 Receivables Convention, Article 1(1)(a).

29 UNCITRAL Receivables Financing: Analytical Commentary on the Draft Convention on Assignment of Receivables in International Trade (Part 1) (UNCITRAL, Vienna, 2001) 12. United Nations Document: A/CN.9/489/Add.1.

30 Except in relation to the debtor: Article 1(3) of the Receivables Convention provides that for the Convention to apply against a debtor, the debtor must be located in a Contracting State or the law applicable to the original contract must be the law of a Contracting State.

31 Receivables Convention, Article 2(a).

32 PPSA, s 17(1)(a) and (b). 


\section{B Effect of Assignment: Anti-Assignment Clauses}

The effectiveness of an assignment is secured, in part, because Article 9 of the Receivables Convention invalidates any contractual limitations on assignments. ${ }^{33}$ Again, the Convention favours the facilitation of credit over the inconvenience of debtors having their legal position altered. Nevertheless, nothing in Article 9 affects any obligation or liability of the assignor for breach of an anti-assignment clause in the original contract. Therefore, depending on the terms of the contract, it is possible for a debtor to sue an assignor for damages resulting from the assignment. Breach of such an agreement, however, cannot result in either the original contract or the assignment contract being avoided. The basis for this rule is that if anti-assignment clauses were allowed to prevail, then a creditor might be inhibited from pursuing finance on the basis of their receivables.

Under the PPSA, a security agreement is effective according to its terms. ${ }^{34}$ This is statutory recognition of the principle of freedom of contract, and consequently, the creditor and debtor are free to draft contacts that suit their interests. ${ }^{35}$ However, the effect of this provision on antiassignment clauses is unclear and reference to the common law is required. The leading decision concerning anti-assignment clauses is the House of Lords decision in Linden Gardens Trust Ltd v Lenesta Sludge Disposals Ltd. ${ }^{36}$ This case concerned the assignment of choses in action between private parties (as opposed to choses in action from a public market), and it outlined several possible effects of such a clause. These are outlined in the transactional analysis to follow but of relevance to this discussion is the fact that the position at common law is not in a definitive state. Consequently, the Receivables Convention has the potential to provide clarity to the law on this issue by providing a clear rule favouring the assignability of receivables.

\section{Effects as Against the Debtor: Discharge of Payment Obligation}

An assignment does not create a contractual relationship between the assignee and the debtor, yet there are many ways that an assignment can affect a debtor. In general, the Receivables Convention favours the facilitation of access to lower cost credit but there are also some provisions that protect the debtor's position. Most obvious is the principle of debtor protection in Article 15 that states that an assignment does not, without the consent of the debtor, affect the rights and

33 Receivables Convention, Article 9(a).

34 PPSA, s 35.

35 Ronald Cuming, Michael Gedye and Roderick Wood Personal Property Securities in New Zealand (Thomson Brookers, Wellington, 2002) 138.

36 Linden Gardens Trust Ltd v Lenesta Sludge Disposals Ltd [1994] 1 AC 85 (HL). This decision, from a superior court in England would be highly persuasive before a New Zealand court. 
obligations of the debtor. ${ }^{37}$ More specifically, Article 15(2) contains a rule prohibiting a payment instruction from changing either the State or the currency of payment specified in the original contract.

The debtor is given a simple discharge rule under the Receivables Convention. The rule provides that after having received notification of an assignment and instruction to make payment to the assignee, the debtor is discharged by paying the assignee. ${ }^{38}$ Until the debtor receives such notification they are discharged by paying in accordance with the original contract. ${ }^{39}$ If having received notification the debtor pays the assignor, then they remain liable to make payment to the assignee. ${ }^{40}$ In addition, the Receivables Convention provides clear rules for cases of multiple notifications relating to several assignments of the same receivable. ${ }^{41}$ As a final point, if the debtor receives notice of the assignment from the assignee, the Receivables Convention states that the debtor is entitled to request that the assignee provide proof of the assignment within a reasonable period of time. $^{42}$

The domestic law of New Zealand depends largely on the time of notice and is governed by the common law. If a party receives effective notification of an assignment then they are required to pay the assignee. ${ }^{43}$ It is no defence that the payment was made to the assignor. ${ }^{44}$ It follows that if the debtor receives effective notice of the assignment and payment is made to the assignor, then the debtor remains liable to pay the assignee. ${ }^{45}$ These rules are highly compatible with the discharge rules in the Receivables Convention.

\section{Priority}

As a transfer of property rights, assignment may affect the rights of third parties who extend credit to the assignor in reliance on the assignor's receivables. If the assignor defaults on payment or becomes insolvent, then creditors will be forced to compete for payment from the assignor's receivables. In the absence of a clear rule as to how such conflicts of priority are to be determined,

37 This principle is supported by the Preamble to the Receivables Convention which states that the drafters of the Convention desired to ensure adequate protection to the interests of debtors.

38 Receivables Convention, Article 17(2).

39 Receivables Convention, Article 17(1).

40 Receivables Convention, Article 17(2).

41 Receivables Convention, Article 17(3)-(6).

42 Receivables Convention, Article 17(7).

43 Magee v UDC Finance Ltd [1983] NZLR 438, 441 (CA).

44 Magee, above, 441.

45 Magee, above, 441. 
the risk of the assignee being unable to obtain payment will be higher. ${ }^{46}$ Furthermore, if this risk cannot be evaluated, a financing transaction may not be concluded, and if the risk can be evaluated, the transaction will take place but its cost will be higher to the assignor and ultimately the debtor. ${ }^{47}$ This problem is further exacerbated by the fact that the systems governing priority are different all over the world. Consequently, there can be a great deal of uncertainty as to the priority of an assignee's right to payment, which can increase the cost of a transaction or even prevent it.

It is not surprising then that the issue of priority caused the greatest conflict during the drafting process for the Receivables Convention. States such as the United States of America who rely upon a registry system advocated a similar system in the Receivables Convention. However, the States that do not use a registry resisted such an approach - partly because of the anticipated cost of registration. ${ }^{48}$ This conflict of legal systems reflects a significant problem in drafting international commercial law - it is inevitable that delegates from each State advocate a system similar to their own.

Unfortunately, agreement on a substantive law rule regarding priority could not be reached and the Receivables Convention is left with a conflict-of-laws approach to priority. A private international law rule provides a clear indicator, since the issue will always be referred to a single and easily determinable jurisdiction, but some delegates questioned the soundness of this approach considering the objectives of the Convention: ${ }^{49}$

The issue seems to have been effectively avoided by ... resort to private international law ... If this proposal is adopted at the next session [and it was] it will in my view make the completion of the convention much easier. However, there is a danger ... that all questions of difficulty might be referred to private international law. In my view a convention which simply referred all problems to the assignor's state of business would hardly be worth drafting.

Commentators generally acknowledge that a substantive law rule would have been preferable but many also acknowledge that this conflict-of-laws pointer is a significant improvement over the present situation. ${ }^{50}$

46 Spiros V Bazinas "Lowering the Cost of Credit: The Promise in the Future UNCITRAL Convention on Assignment of Receivables in International Trade" (2001) 9 Tul J Int'l \& Comp L 259, 283.

47 Bazinas, above.

48 Mara E Trager "Towards a Predictable Law on International Receivables Financing: The UNCITRAL Convention" (1999) 31 NYU J Int L \& Pol 611, 629.

49 Trager, above, 631. This reference is from footnote 101 of Trager's article which cites this comment to a letter to the author from Christopher Doyle, Office of the Attorney General, 10 November 1997.

50 Sprios V Bazinas "Lowering the Cost of Credit: The Promise in the Future UNCITRAL Convention on Assignment of Receivables in International Trade" (2001) 9 Tul J Int'l \& Comp L 259, 286. 


\section{Priority rule: conflict-of-laws}

The Receivables Convention provides that priority is to be determined by reference to the law of the assignor's location. ${ }^{51}$ This is subject to two important exceptions. The first is if the application of the law of the assignor's State is manifestly contrary to public policy. ${ }^{52}$ The second is if the special rules on proceeds as outlined in Article 24 are applicable. ${ }^{53}$ In such a scenario, Article 24 will trump the law of the assignor.

Section 30 of the PPSA is the relevant provision domestically. It provides that the validity, perfection, and effect of perfection or non-perfection of a security interest in an intangible is subject to the law of the jurisdiction where the debtor is located when the security interest attaches. The location of the debtor is determined having reference to section 29.54 Confusion could arise since under the definition of "debtor" provided in section 16, both the assignor and the person who is obliged under the account receivable are classified as debtors. Consequently, it is necessary to determine which debtor is referred to for the purposes of each section. It is submitted that for the purposes of section 30 it is the assignor that is the relevant debtor. With respect to the assignment of accounts receivable, section 102 of the PPSA defines the assignor as the debtor and the person obligated under an account receivable as the account debtor. Therefore, under this relationship it would appear that the debtor to which section 30 refers is the assignor as opposed to the account debtor. In this regard, the rule is consistent with the Receivables Convention.

In addition, the PPSA provides a statutory rule governing situations where the law of the debtor does not provide for public registrations of security interests. In such a scenario, the assignee could

51 Receivables Convention, Article 22. The location of the assignor is determined having reference to Article 5(h):

A person is located in the State in which it has its place of business. If the assignor or the assignee has a place of business in more than one State, the place of business is that place where the central administration of the assignor or the assignee is exercised. If the debtor has a place of business in more than one State, the place of business is that which has the closest relationship to the original contract. If a person does not have a place of business, reference is to be made to the habitual residence of that person.

52 Receivables Convention, Article 23(1)

53 Receivables Convention, Article 24. The purpose of these special rules are to facilitate payment to the assignee. UNCITRAL Receivables Financing: Analytical Commentary on the Draft Convention on Assignment of Receivables in International Trade (Part 2) (UNCITRAL, Vienna, 2001) 17. United Nations Document: A/CN.9/489/Add.1.

54 Personal Property Securities Act 1999, s 29:

(a) A debtor that is a body corporate is located in the country of incorporation; and (b) A debtor that is not a body corporate is located at - (i) The debtor's place of business; or (ii) The debtor's principal place of business (if the debtor has more than 1 place of business); or (iii) The debtor's principal residence (if the debtor has no place of business). 
not search a foreign registry to determine whether the personal property was subject to a security interest. To mitigate this result, the Act provides that the unregistrable security interest is subordinate to an account receivable payable in New Zealand. The Receivables Convention does not make a similar policy decision. If the law of the assignor is the law of a State without a registration system then the priority rules of that State are still applicable.

\section{Priority: optional annex for registration}

The Receivables Convention contains several optional and alternative substantive law rules for determining priority with respect to assigned receivables. A State must opt into these provisions and, when they do, the provisions of the Annex selected will supplant the national law of that State. From New Zealand's perspective, the preferable option is priority based on registration, as that is parallel with the rules in the PPSA. Under this regime, the first to register in accordance with Section II of the Optional Annex has priority. The registry would be international, searchable and would record information about assignments. Clearly, a high degree of certainty with respect to competing claimants would be achievable under this regime, as registration will ensure priority. Furthermore, the registry will reveal the competing claimants, which will allow an assignee to determine whether and who the competing claimants are before they enter into the transaction. This approach would be highly consistent with the domestic law in New Zealand vis-à-vis the PPSA.

\section{E Initial Conclusions on the Receivables Convention}

The promise of the Receivables Convention is an international uniform regime to govern the international assignment of receivables. From New Zealand's perspective, many of the rules in the Receivables Convention are highly consistent with those in the PPSA. Consequently, ratifying the Receivables Convention would not be a major departure from the current domestic law. In addition, if a significant amount of States ratified the Receivables Convention then it would have the effect of bringing uniform laws in this area that closely compare with New Zealand's domestic laws. However, despite this promise, the ultimate success of the Convention will depend upon its effect in practice, not in theory. For the purposes of this paper, the relevant enquiry is into the Receivables Convention's effect of trans-Tasman receivables financing.

\section{SAMPLE TRANSACTION: SUBSTANTIVE LAW ISSUE}

Anti-assignment clauses are routinely included in contracts and will sometimes result in the invalidation of an assignment. ${ }^{55}$ As a result, the creditor in a sales transaction may not be able to obtain financing on the basis of their receivables. This is because a potential financier (the assignee) will be cautious when providing credit owing to the uncertainty of the validity of their interest.

Consider the following sample transaction:

55 Linden Gardens Trust Ltd v Lenesta Sludge Disposals Ltd [1994] 1 AC 85 (HL). 
In the ordinary course of business, NZ Inventory Supplier (NZIS) supplies inventory to its customers on credit. ${ }^{56}$ Customers pay their accounts when due as arranged. However, NZIS is in need of finance and decides to sell the right to collect these account receivables to NZ Factor (NZF). One of the debts owing stems from the contract with an Australian Purchaser (AP). The AP is immediately notified of the assignment and is instructed to make payment to NZF. However, included within the sales contract is a clause that states: "NZIS will refrain from assigning the right to receive payments arising under this contract of sale". ${ }^{57}$

Believing this assignment to be ineffective owing to the contractual provision against assignments, the AP continues to pay NZIS as accounts fall due. Unfortunately, NZIS is declared insolvent. No account was made by them to NZF. It is anticipated that upon liquidation there will be no funds for NZF to claim from NZIS. Consequently, NZF is seeking payment from the AP on the basis of an effective assignment and the AP's failure to discharge the payment obligation. The AP resists on the basis of the anti-assignment clause, claiming that there was no effective assignment, and therefore, the payment to NZIS effectively discharged their payment obligation. Considering only the anti-assignment clause: does the anti-assignment clause prevent NZF from claiming payment from the AP?

\section{A Analysis in Absence of the Receivables Convention}

\section{Applicable law}

The first issue a court will need to decide is what the applicable law is. ${ }^{58}$ Since the antiassignment clause is contained within an international sales contract, the court will look to it to determine the applicable law. If the parties included an applicable law clause, then the court would likely give effect to it, provided that it is bona fide and legal, and is not contrary to public policy. ${ }^{59}$ In the absence of a choice of law clause, which is sometimes the case even when large sums of money are involved, ${ }^{60}$ the court will refer to the objective proper law of their contract. This is

56 NZIS supplies on a retention of title basis as outlined in their contract.

57 This clause was specifically negotiated for as the AP is a relatively small company and while they are confident entering into business relations with NZIS, they do not wish to enter into business relations with unknown parties.

58 This is true irrespective of whether the case is heard before a New Zealand or an Australian court.

59 Vita Foods Products Inc v Unus Shipping Co Ltd [1939] AC 277, 290 (PC); Starlink Navigation Ltd v The Ship "Seven Pioneer" (12 February 2001) High Court, Auckland AD 9181/98, Hansen J. If the case was before a New Zealand court and there was a choice of law clause identifying Australian law as the applicable law, then the court would apply Australian law unless the application of Australian law was contrary to public policy in New Zealand.

60 See for example McConnell Dowell Constructors Ltd v Lloyd's Syndicate 396 [1988] 2 NZLR 257 (CA). Here there was no choice of law clause in an insurance agreement involving several million dollars entered into by a New Zealand based group of companies involved in construction throughout the Asia-Pacific 
generally defined as the system of law with which the relevant transaction has its "closest and most real [connection]". 61

Undoubtedly, the determination of the applicable law is a complex matter and will result in increased litigation costs. Furthermore, at the time of assignment, NZF will not be sure of the applicable law. This creates uncertainty concerning the enforceability of their interest and ultimately will affect the cost of credit. ${ }^{62}$ Once the applicable law is determined more uncertainty awaits the resolution of the effect of the anti-assignment clause.

\section{Law applied to facts}

If the court determined that the law of New Zealand was applicable, then reference to the PPSA is required since the sales transaction creates an interest in personal property. ${ }^{63}$ The discussion in the previous section made clear that the PPSA recognises the principle of freedom of contract, subject to limitations. ${ }^{64}$ However, the PPSA is not a complete code of all the law applicable to personal property security transactions. Thus, when there are gaps in the legislation recourse to the common law is necessary. It is submitted that the effect of an anti-assignment clause is a gap in the legislation because the issue is not resolved within the PPSA. Consequently it is necessary to apply the common law to the resolution of this issue. ${ }^{65}$

In both Australia and New Zealand the effect of an anti-assignment clause, in relation to choses in action, is determined by the common law. ${ }^{66}$ Since the leading decisions will be highly persuasive

region, and a London-based multinational syndicate providing global insurance. As cited from Barnard "Choice of Law in International Contracts (1996) 2 NZBLQ 29, 34.

61 Bonython v Commonwealth of Australia [1951] AC 201, 219 (PC). The New Zealand Court of Appeal adopted this formulation in McConnell Dowell Constructors Ltd v Lloyd's Syndicate 396 [1988] 2 NZLR 257, 273 (CA). There are a myriad of factors that the court will consider in this inquiry, including: the parties' places of business, the place where the contract was concluded, and the place where the subject matter of the contract is located.

62 The more uncertainty surrounding the ability of the factor to collect the payment, the less the factor will be willing to pay parties in the position of NZIS. Trade New Zealand reports that the creditor (NZIS) receives around 80 per cent of face value for the sale of their receivables in a typical factoring transaction. Trade New Zealand <http://www.tradenz.govt.nz/page_Article/0,1300,4231\%252D847,00.html > (last accessed 31 July 2002).

63 PPSA, s 17(1)(a). The transaction secures payment.

64 It was also pointed out that there are limitations to this freedom, such as the priority rules in the PPSA they cannot be contracted out of.

65 Support for this comes from the fact that s 35 is concerned with the effectiveness of the security agreement. The issue of the effect of the anti-assignment clause does not affect the security agreement between NZIS and the AP - it impacts on the rights of the assignee (NZF).

66 PPSA, s 102 provides that the rights of an assignee (NZF) of an account receivable are subject to the terms of the contract between the account debtor (AP) and the assignor/debtor (NZIS). The result is that NZF's 
in both countries, it is possible to consider the domestic law of each country together. In this sense, there is not disparity between the law between Australia and New Zealand. However, the present state of the law in each country is in an unsatisfactory state and the Receivables Convention offers the possibility to provide a clear rule across the Tasman that will favour receivables financiers.

The law in both Australia and New Zealand permits parties to a contract to stipulate that one of the parties cannot assign the benefits they receive under the contract to third parties. ${ }^{67}$ However, consequences of an anti-assignment clause are a matter of construction for the court and the law is not in a definitive state. Vastly different outcomes are possible.

There is no decision directly on point to these facts but the leading authority in the Commonwealth with respect to the effect of an anti-assignment clause generally is Linden Gardens Trust Ltd v Lenesta Sludge Dispotals Ltd. ${ }^{68}$ Several different outcomes are enumerated: first, the term does not invalidate a purported assignment but gives the account debtor a claim for damages against the assignor for breach of the prohibition. ${ }^{69}$ Second, the term precludes the assignment but does not prevent the assignor from agreeing with the assignee to account for the payments. ${ }^{70}$ Third, the assignor is prevented from assigning the contractual rights and from agreeing to account to the assignee. ${ }^{71}$ Finally, the assignment in breach of an anti-assignment clause is ineffective to transfer the chose in action to the assignee. ${ }^{72}$ The court has essentially listed all possible effects that an antiassignment clause can have as potential outcomes in the case of a dispute. Ultimately, it is question of construction whether a contractual stipulation that prohibits assignment is effective. ${ }^{73}$

Applied to the present dispute, it is difficult to determine what effect the court would attribute to this clause. Essentially, the legal position of the AP remains unchanged except that they are now

right to receive payment is subject to the anti-assignment clause within the sales contract. Whether the clause operates to prevent NZF from claiming payment from NZIS is not determined in the PPSA but must be determined by the common law.

67 Garry Denning Ltd v Vickers [1985] 1 NZLR 567, 570 (CA) Woodhouse P; Helstan Securities Ltd v Hertfordshire County Council [1978] 3 All ER 262, 266 (CA). In Helstan Securities, it was found that a provision in a contracting contract for roadworks that the contractor was not to "assign the contract or any part thereof or any benefit or interest therein or thereunder without the written consent of the employer" rendered an assignment of that contract invalid. The ability of the employer to retain control of who does the work was a significant factor.

68 Linden Gardens Trust Ltd v Lenesta Sludge Disposals Ltd [1994] 1 AC 85 (HL) [Linden Gardens].

69 Linden Gardens, above, 104, Lord Browne-Wilkinson.

70 Linden Gardens, above.

71 Linden Gardens, above.

72 Linden Gardens, above.

73 Simon Fisher Commercial and Personal Property Law (Butterworths, Sydney, 1997) 621. 
requested to make payment to NZF rather than NZIS. Since this transition does not require a change in either the country of payment or the currency, it is difficult to conceive that the change of payment is a burden. However, if the AP has an established business relationship with NZIS, then they might be able to expect more leniency with respect to late payment - this goodwill might not be extended by NZF who is likely to be a stranger to the AP. Essentially, based on previous business relations, the AP could argue that their business relationship with NZIS was based on trust and confidence. This could build a strong argument for resisting relations with unknown third parties.

Ultimately, in the present example, it is uncertain what effect the court would attribute to this clause by either New Zealand or Australian law. Most importantly, the absence of a clear rule means that financiers like NZF, in the above example, will not be certain of the enforceability of their interests when an anti-assignment clause is in the original sales contract. The result is that the assignee faces the possibility of having their assignment invalidated. Consequently, such transactions might be discouraged, or the cost of credit to companies in the position of NZIS will be increased.

\section{B Analysis if Convention Applicable}

In the present example, the receivable is international since at the time of conclusion of the contract from which the receivable arises, the assignor (NZIS) and the debtor (AP) are located in different states. ${ }^{74}$ Therefore, the receivable is within the ambit of the Receivables Convention. However, there must still be a nexus to a Contracting State. For the Convention to apply, the assignor must be in a Contracting State. ${ }^{75}$ Consequently, in the present example the Receivables Convention will be applicable if New Zealand is a Contracting State since NZIS (assignor) is located in New Zealand. This is true irrespective of whether the State of the debtor has adopted the Receivables Convention - in this case Australia. If Australia is a Contracting State and New Zealand is not, then the Receivables Convention will not be applicable and the court must have reference to the applicable national law. The remainder of this analysis proceeds on the basis that New Zealand is a Contracting State and that the Convention is applicable.

Once the court determines that the assignor's State is a Contracting Party it becomes unnecessary for the court to enter into any further complex applicable law analysis. So long as the court is satisfied that the Receivables Convention is applicable to the dispute then it will only be necessary for the court to look to the Convention to determine the effect of the anti-assignment clause. By extension, the assignee need only determine whether the assignor is in a Contracting State in order to know the applicable law at the time of concluding the assignment contract. This will have a beneficial effect because the assignee will have increased certainty about the law

74 Receivables Convention, Article 3.

75 Receivables Convention, Article 1(1)(a). 
applicable to their interest. This increased certainty should lower the cost of credit since the assignee will not have to make detailed inquiries into foreign law on matters settled in the Convention such as anti-assignment clauses.

In addition, the Convention settles this issue in a manner that is much more certain then the domestic law of either Australia or New Zealand. The rule in the Convention is clear. An assignment of a receivable is effective notwithstanding any agreement between the assignor (debtor in PPSA terms) and debtor (account debtor in PPSA terms), limiting in any way the assignee's right to assign its receivables. ${ }^{76}$ As a result, in situations such as the present example, the adoption of the Receivables Convention by New Zealand will invalidate a contractual term with an Australian entity (AP) irrespective of Australia's decision not to adopt the Convention. The rule clearly favours the assignability of receivables. If assignments are invalidated and the assignee is deprived of the right to collect from the debtor, the availability and cost of credit to the assignor will be negatively affected. The addition of this clear rule to trans-Tasman receivables financing will have the beneficial effect of bringing both harmony and certainty to the law in this area.

\section{SAMPLE TRANSACTION: CONFLICT-OF-LAWS ISSUE}

A lender who provides credit on the security of receivables needs to ensure that its security will be enforceable against third parties. The commercial value of the security right depends on whether the holder of the right will be entitled to priority against competing claimants, such as another secured creditor, a purchaser of the collateral, or an insolvency administrator. Some legal systems contain specific provisions intended to solve priority disputes among competing claimants. Absence of clear rules in this regard deters the use of receivables as collateral. ${ }^{77}$ This problem is compounded in a trans-Tasman transaction, where there is uncertainty as to which law will apply to settle a potential conflict of priority between competing claimants purporting to have a right to the receivable. Further complications arise from the generally confusing state of the Australian law in this regard.

Consider the following example:

On 1 January 2002, Australian Bank (AB) advances credit to New Zealand Inventory Supplier (NZIS), secured by way of debenture in the form of a floating charge over the assets of NZIS. The terms of the debenture extend to all 'present and after acquired property' of NZIS. In the ordinary course of its business, NZIS supplies inventory to its customers on credit. ${ }^{78}$ Customers pay their

76 Receivables Convention, Article 9(1). However, under Article 9(2), the Receivables Convention does not prevent any existing action for damages against the assignor from the debtor.

77 Michel Deschamps "The Priority Rules of the United Nations Receivables Convention" (2002) 12 Duke J Comp \& Int'l L 389, 391.

78 NZIS supplies on a retention of title basis as outlined in their contract. 
accounts when due as arranged. One such customer is an Australian Purchaser (AP) who was supplied inventory from 1 March 2002 as required.

NZIS begins to experience cash flow problems and decides to sell the right to collect these accounts to NZ Factor (NZF). The date of the assignment is 2 June 2002. Some of the debts owing stem from the contract with the AP. Unfortunately, this measure did not alleviate NZIS's financial difficulties, and on 30 June 2002, NZIS entered into insolvency proceedings before the AP had made any payments on their outstanding accounts. The AP owes the money for the inventory supplied - but to whom? There is a priority dispute between AB and NZF. Considering only the issue of priority, who has the better right to receive the remaining payments?

\section{A Analysis in Absence of Receivables Convention}

\section{Applicable law}

There is an international element to this conflict and irrespective of the jurisdiction in which the conflict is heard the applicable law will have to be determined. Since the conflict-of-laws rules in Australia and New Zealand are considerably different it is necessary to consider each separately.

If the case is heard in a New Zealand court, then the conflict rules in the PPSA will apply. This is because the dispute is a priority conflict concerning intangibles (account receivables) and the PPSA provides specific conflict rules governing this situation. The PPSA is a statutory override of the common law priority rules in this regard. Section 30 of the PPSA is the relevant provision and it points the court to the law of the location of the debtor when the security interest attaches. ${ }^{79}$ This is a clear rule but there is an issue concerning the identity of the relevant debtor for this provision.

Under the definition of debtor provided in section 16, both NZIS and the AP are classified as debtors. ${ }^{80}$ As a result, it is necessary to determine which debtor is referred to for the purposes of section 30. The consequence of this finding is significant, as it will point to the law of a different state - either New Zealand or Australia in the present dispute. It is submitted that for the purposes of section 30, the assignor, NZIS is the relevant debtor. The section is concerned with the collateral, in this case an intangible being an account receivable. With respect to the assignment of accounts receivable, section 102 of the PPSA defines the assignor as the debtor and the person obligated under an account receivable as the account debtor. Therefore, under this relationship it would

79 PPSA, s 29 determines the location of the debtor:

(a) A debtor that is a body corporate is located in the country of incorporation; (b) A debtor that is not a body corporate is located at - (i) The debtor's place of business; or (ii) The debtor's principal place of business (if the debtor has more than 1 place of business); or (iii) The debtor's principal residence (if the debtor has no place of business).

80 PPSA, s 16. Debtor includes both a person who owes payment or performance of an obligation secured, such as the AP, and a transferor of an account receivable, such as NZIS. 
appear that the debtor in which section 30 of the PPSA refers is the assignor, as opposed to the account debtor. The result is that the law of New Zealand will apply to the priority conflict since NZIS is the assignor and they are located in New Zealand.

If it had been determined that the law of Australia was applicable then an issue might arise under section 32(1)(a) of the PPSA. This provision applies when the law applicable is that of a jurisdiction that does not require public disclosure of the existence of a security interest. Under such circumstances, the security interest is subordinate to an account receivable payable in New Zealand. Consequently, if Australian law applied and there was no provision for public registration of the relevant security interest, then that security interest would be subordinated to an account receivable payable in New Zealand.

If the case is brought before an Australian court then determining the applicable law is considerably more complex. There is no uniform personal property securities Act in Australia, and correspondingly, no uniform conflicts rule. For the most part the applicable law is governed by the conflict rules of the common law. ${ }^{81}$ Under the law in Australia, the property in question in the present example is a chose in action since the payment owed is essentially a debt. With respect to the issue of priority, the authority is not in a definitive state but application of the proper law of the debt, the law applicable where a thing is located - the lex situs - is the most likely to be applied by an Australian court. ${ }^{82}$ Consequently, if this case were brought before an Australian court it appears that the court would apply Australian law since the debt, which is the subject of the assignment, is located there with the AP. ${ }^{83}$

\section{Law applied to facts}

If the court hearing the matter applied New Zealand law to this priority conflict, then much will depend upon the time of registration of a security interest. ${ }^{84}$ Section 66 of the PPSA is the

81 Subject to statutory fragments of conflict rules governing specific situations.

82 Australian Mutual Provident Society v Gregory (1908) 5 CLR 615 (HCA). This case involved the beneficiary of a Tasmanian estate who became bankrupt in South Africa. Under the law of South Africa his bankruptcy effected an assignment of his interest in the Tasmanian estate. Subsequently, he executed in Tasmania an assignment of the same interest to the Australian Mutual Provident Society. The High Court determined that the question of priorities should be determined by Tasmanian law as that was the location of the interest and its place of administration - the lex situs.

83 The debt at issue here is the account receivable owed by the AP to NZIS. There is an argument to be made that the debt is located in New Zealand as that is where the payment is made. However, this author concludes that an Australian court is likely to determine that the debt is located in Australia as that is where the account debtor is located - and thus within the jurisdiction of the Australian court.

84 The definition of security interest in the PPSA includes outright transfers of accounts receivable and transactions in which a bank takes a security interest in all of a debtor's present and after acquired property which includes the debtor's account receivables. 
governing provision. The assignment of receivables are a deemed security interest under the PPSA and thus within the scope of the Act. ${ }^{85}$ Assuming that both AB and NZF registered financing statements in accordance with the Act, then the relevant rule states that priority between perfected security interests is accorded to the first in time to register a financing statement. ${ }^{86}$ Consequently, so long as $\mathrm{AB}$ registered a security interest before NZF then they will have priority to the payments from the AP.

It must be mentioned that depending upon the use for which the credit was extended, $A B$ may be able to claim a "purchase money security interest" over the accounts receivable. ${ }^{87}$ This would arise if NZIS applied the credit supplied by AB to purchase the inventory that was the subject of the contract of sale with the AP. In such a scenario, a party in the position of NZF would have their security interest defeated even if they registered a finance statement prior to AB. ${ }^{88}$ Therefore, NZF should search the registry to determine whether a secured party has already taken an interest in the accounts receivable.

If Australian law applies then the resolution of this priority conflict is much more confusing as the rules are less clear than in New Zealand. The rules governing priority are a mixture of common law, equity, and statute. Much depends upon the nature of the transaction, the identity of the debtor, the type of collateral, and whether the assignee gained a legal or an equitable interest. ${ }^{89}$

The general rules applicable to a priority conflict are summarised by Mahoney $\mathrm{J}$ in Reynolds Bros (Motors) Pty Ltd $v$ Esanda Ltd. ${ }^{90}$ If the assignee (NZF) acquired a legal interest in the company assets subject to a floating charge, and they did not have knowledge of the existence of the floating charge, then the assignee will hold the interest free of the equitable floating charge. ${ }^{91}$ Where the assignee takes an equitable interest then the priority dispute is resolved in favour of the interest that is earlier in time - in this case the floating charge. ${ }^{92}$ However, if the later equity (NZF interest) is acquired by its holder in the ordinary course of the company's business, then it will

85 PPSA, s 17(2).

86 PPSA, s 66(1)(b).

87 PPSA, s 16. Essentially, a "purchase money security interest" arises when a security interest is taken in collateral by the seller to the extent that it secures the obligation to pay all or part of the collateral's purchase price.

88

PPSA, s 74.

89 Australian Law Reform Commission Personal Property Securities (ALRC R64, Canberra, 1993) 19.

Reynolds Bros (Motors) Pty Ltd v Esanda Ltd (1983) 8 ACLR 422, 427-428, Mahoney J.

91 Reynolds Bros, above.

92 Reynolds Bros, above. 
prevail over the earlier floating charge. ${ }^{93}$ This is because the nature of the floating charge allows for later equities to be created.

Applied to the present facts, if the assignment of the receivables to NZF satisfied the requirements for a legal assignment under section 130 of the Property Law Act 1952, then its interest will prevail over the earlier floating charge. If however the assignment is determined to be an equitable assignment, then for NZF to prevail it will have to be demonstrated that it made the assignment in the ordinary course of its business. If NZIS cannot establish this, then the general rule for competing equitable assignments will apply and the first in time - $\mathrm{AB}$ - will prevail. The resolution of this issue is complex, and, most importantly, NZF will not be sure of the priority of its interest at the time of the assignment.

\section{B Analysis if Receivables Convention Applicable}

As examined under the analysis of the previous sample transaction, for the Receivables Convention to be applicable, the assignor - NZF - will have to be located in a Contracting State. ${ }^{94}$ Consequently, New Zealand would have to be a Contracting State. The receivable would be within the scope of the Receivables Convention since NZF and AP are located in different States. ${ }^{95}$ If New Zealand were not a party to the Receivables Convention but Australia was a party, then the court would need to have recourse to the relevant domestic law. However, the remainder of this analysis presupposes that New Zealand is a Contracting State, and thus, that the Receivables Convention is applicable to the dispute.

The Receivables Convention aims to reduce the uncertainty surrounding priority issues by providing an easy rule for the determination of the body of laws to be used to solve priority conflicts. Any conflict involving an international assignment or an international receivable will be resolved by reference to one single law - the law of the location of the assignor. ${ }^{96}$

The benefits of this rule in a trans-Tasman context is that the assignee, whether in Australia or New Zealand, will be able to determine the applicable law governing the priority of their interest by referring only to the law of the assignor. This will provide additional certainty in a trans-Tasman context because the determination of the applicable law in Australia is confusing and subject to many factors. The result is that if the assignor is located in New Zealand, then the PPSA will determine the priority dispute. Correspondingly, if the assignor is located in Australia, then

93 Reynolds Bros, above.

94 The Receivables Convention, Article 1(1)(a).

95 Receivables Convention, Article 3.

96 Receivables Convention, Article 22. The assignor is the debtor in PPSA terms. The location of the assignor is determined having reference to Article 5(h). 
Australian law will apply. In such a scenario, the location rules are of considerable importance, and the Receivables Convention provides clear rules. ${ }^{97}$

The limitation of this approach is that the law is not made uniform. With the Receivables Convention in force, parties will always have to meet the priority requirements of the applicable law, which is substantially different between New Zealand and Australia. The only way that harmonisation is achievable on this issue is if both New Zealand and Australia opt into the Receivables Convention's Optional Annex. This Annex provides for substantive law priority rules and an international registry.

\section{Analysis if Optional Annex Applicable}

If both Australia and New Zealand opted for the priority rules as outlined in section I of the Annex, in combination with the conflict-of-laws priority provisions, then uniformity on this issue would be achieved. This combined situation would not create any conflict situations as the substantive law priority provisions of the Receivables Convention and the law governing priority would be the law of the same country - the country in which the assignor is located. This situation would create the utmost certainty for the assignee because they could determine at the time of assignment both the applicable law and the applicable rule. The priority rules based on registration are determined by the order in which data about the assignment is registered under section II of the Annex. This rule will be familiar to New Zealand parties as it is consistent with the PPSA, but it will be a departure from the present situation in Australia. It does, however, reflect the Australian Law Commission's recommendation on priority in Australia. ${ }^{98}$ Consequently, if Australia opted into the Optional Annex, then the degree of certainty would be achieved with respect to the priority of security interests that many commentators in Australia feel is long overdue. For New Zealand, the adoption of the Optional Annex would have the benefit of applying a rule in an international context that is highly consistent with domestic rules. In such circumstances, uniformity and certainty would be achieved and transactions would be both simpler and cheaper.

\section{CONCLUSIONS AND FUTURE CONSIDERATIONS}

The first part of this analysis identified that there are differences between the New Zealand and Australian laws governing receivables financing. New Zealand enacted the PPSA, and while the benefits of this legislation are yet to be demonstrated, most commentators believe that the Act will simplify the domestic laws of New Zealand for receivables refinancing. The law in Australia however, remains complicated, fragmented, and generally confusing. This legal quandary in

97 For this reason, it would be prudent for an assignee to search the registry (if applicable) of the State where the company has its place of central registration, if the assignor has more than one place of business. Under the Receivables Convention, Article 5(h), if the assignor has more than one place of business than they are deemed to be located in the place where their central administration is.

98 Australian Law Reform Commission Personal Property Securities (ALRC R64, Canberra, 1993) 19. 
Australia awaits New Zealand parties entering into trans-Tasman receivables financing transactions. Correspondingly, Australian parties will have to work within the New Zealand PPSA, a legal framework fundamentally different from their own. The result is that parties entering into transTasman receivables financing transactions must investigate and sometimes satisfy the law in two or more jurisdictions. This increases the cost of the transaction. In addition, financiers, like the factors in the sample transactions, are less certain of the enforceability of their interest than they would be domestically; and this will lower the cost of credit.

In response to this situation there has been a call for the harmonisation of international commercial laws generally, and the laws governing receivables financing specifically. The CER has long recognised the benefits in the harmonisation of trans-Tasman commercial laws, and it seeks to promote this process. In addition, the New Zealand Law Commission has commented on the perceived benefits in international harmonisation including increased certainty and lower transaction costs. To achieve this end in the field of receivables financing, the UNCITRAL developed the Receivables Convention.

The second part of the analysis in this paper outlined the rules in the Receivables Convention and assessed their compatibility with the domestic laws of New Zealand. This demonstrated that there is a high degree of compatibility between these legal regimes. One reason for this might be the influence of the United States of America on UNCITRAL, and the similarity of New Zealand's PPSA with Article 9 of the United States Uniform Commercial Code, which governs secured transactions. The result for New Zealand is that if the Receivables Convention is widely adopted, then an international legal regime governing receivables financing will be established that is similar to New Zealand's domestic laws. This will benefit New Zealand parties, including those entering into trans-Tasman transactions, by bringing increased certainty since the applicable law will closely resemble that in New Zealand.

The Receivables Convention is however, currently only a theoretical document as it has not entered into force. To analyse the effect of the Receivables Convention in a trans-Tasman context, it was necessary to apply the Convention to some sample transactions as was done in the final part of this paper. This analysis demonstrated that when the Receivables Convention is not applicable, parties to trans-Tasman receivables transactions face complicated applicable law arguments and general uncertainty concerning the resolution of legal issues. In the case of a dispute, this will result in increased litigation costs. Furthermore, there is a degree of uncertainty concerning the enforceability of an assignee's interest at the time of assignment, which will negatively impact the cost of credit.

When the Receivables Convention is applicable to the transaction the need for a complicated applicable law analysis, in the case of a dispute, is nullified. This is because the court need only determine whether the state of the assignor is a Contracting Party to determine if the Convention is applicable. Furthermore, when the Receivables Convention establishes a substantive law rule, like in the case of an anti-assignment clause, then both certainty and harmony are achieved. However, 
leaving the important issue of priority to a conflict-of-laws pointer is a major shortcoming of the Receivables Convention. The result is that uniformity is not achieved for this most important issue since the parties will always have to satisfy the applicable law - that of the assignor. The Optional Annex on registration and priority offers the possibility of achieving uniformity in this area but it is unlikely that states, such as Australia, that have fundamentally different domestic laws would opt into this Annex.

Finally, some comment should be made concerning the likelihood of the Receivables Convention entering into force in either New Zealand or Australia. The author contacted the Ministry of Foreign Affairs and Trade, the responsible Ministry in New Zealand, and the following opinion was provided: ${ }^{99}$

The New Zealand Government has not yet formed any firm position on whether or not to become party to the convention, and much will depend on whether the convention is widely subscribed. In the short term, the New Zealand Government will monitor the convention's status, but is unlikely to be undertaking substantive work in relation to the convention. If there is widespread ratification, the Government would then undertake further work on the implications of becoming a party.

New Zealand was not involved in the drafting process and clearly, New Zealand is currently taking a wait-and-see approach to the ratification of the Receivables Convention. Australia was involved in drafting the Receivables Convention but currently they are not taking a proactive approach to ratification. The Ministry responsible in Australia provided the following opinion: ${ }^{100}$

In short, we are presently undertaking consultations with stakeholders and have yet to make a decision on whether Australia will ratify the Convention. I do not imagine that we will be in a position to make a decision on whether to ratify the Convention until next year.

In view of the present opinions, it appears that parties in New Zealand and Australia will have to wait some time before the benefits of the Receivables Convention are realised across the Tasman. In the meantime, the reform process continues in Australia, and the enactment of an Australian personal properties securities Act would likely bring a degree of uniformity to the laws across the Tasman governing receivables financing.

99 Received by email (19 July 2002) from Stephen Wong, Legal Division Ministry of Foreign Affairs and Trade. Permission sought and granted to reproduce this statement.

100 International Trade and Environment Law Branch, Office of the Attorney General's Department, the Ministry responsible in Australia. Opinion received by email (20 August 2002) from Joshua Brien, Assistant Secretary. Permission sought and granted for the reproduction of this statement. 